\section{Core of}

\section{controversy}

over biohazards

\section{Sheldon Krimsky}

The Recombinant DNA Debate. Edited by

D.A. Jackson and S.P. Stitch. Pp.385. (Prentice-Hall International: Englewood Cliffs, New Jersey, and Hemel Hempstead, UK, 1979.) £14.55.

THE controversy of the past eight years over the regulation of recombinant DNA techniques has left in its wake some unusual and vexing policy issues. For the non-molecular biologist peering through the key-hole at the disputants, listening to a genetic vernacular that could pass as extraterrestrial noise, the debate gives the appearance of a family feud. And it might have remained just that way were it not for the scientists who alerted the public to the potential hazards of their own work. Given the public's concern about this area of research and development, scientists may view similar acts of social responsibility as a danger to their disciplinary autonomy.

The principal target population affected by controls and regulation is a group of scientists engaged in basic research. Consequently, predominant expertise resides with a major interest group. The experts who are called upon to guide us through a safe technology path and on whom we must depend for objectivity can hardly qualify as impartial. Paradoxically, without them there could be no risk assessment.

The recombinant DNA episode holds many riches for science-watchers. It has stimulated discussion on a wide range of problems from public participation in the formation of science policy to the future prospects for human genetic engineering. In their edited volume The Recombinant DNA Debate David A. Jackson and Stephen P. Stich provide a series of essays that reach the central core of the scientific controversy over biohazards and, in addition, examine some of the moral and legal issues involved in the regulation of scientific inquiry. Stich, a philosopher, was on the faculty of the University of Michigan during the period the volume was in preparation. David Jackson, a University of Michigan microbiologist, was senior author of the first published paper on recombinant DNA techniques. Jackson also helped establish Genex, a US firm set up to develop commercial uses for recombinant DNA techniques.

The book, consisting of seventeen papers written between 1975 and 1977, is divided into three sections: Part I introduces the non-specialist to the techniques of genetic engineering; Part II examines the risks and benefits from various sides of the controversy; and Part III considers legal, social and philosophical issues. Most of the scientific contributors have also been principal actors in the debate (A.M. Chakrabarty, Roy Curtiss III, Bernard D. Davis, Joshua Lederberg, Robert Sinsheimer and George Wald). For this review I shall limit my comments to selected essays.

A.M. Chakrabarty reviews the areas in which recombinant DNA techniques may prove fruitful. These include drug, chemical and fuel manufacturing, crop improvement, and the treatment of genetic disorders. It is too early to judge whether or not Chakrabarty's optimism that recombinant DNA, by revolutionising the manufacture of biologically active proteins, "would make them available in large quantities at modest cost and would contribute significantly to the betterment of human health and welfare.". It is perhaps a symptom of the snail's pace of technology assessment that neither in this volume nor in the vast literature on this subject does their exist an analagous technical discussion of areas of potential misapplication or willful misuse of recombinant DNA technology.

Roy Curtiss III describes his con struction of a strain of E.coli with twentyfour specific mutations designed to render it safe for molecular cloning. While initially an integral part of a strategy for biological containment, the skillfully engineered strain of $E$.coli (Chi 1776) may soon be irrelevant for the vast majority of experiments in the US. Recently, the Recombinant DNA Advisory Committee of the National Institutes of Health (NIH) voted to exempt most experiments from the NIH guidelines when ordinary laboratory strains of E.coli $\mathrm{K} 12$ are used. Little incentive remains for scientists to continue using the highly sensitive Curtiss strain despite its widely acclaimed safeguards.

Papers outlining the potential dangers of gene-splicing are contributed by Robert Sinsheimer, George Wald, and the recombinant DNA study group of Science for the People. Both Sinsheimer and Wald implore their colleagues to consider the long-term ecological consequences of this new-found power to rearrange genetic substance across widely divergent species. Their emphasis is on the possibility of unexpected events or "evolutionary booby-traps", in contrast to specific scenarios of danger.

As a counterpart to the DNA critics, there are contributions by Bernard D. Davis and Rolf Freter focusing on imagined, as opposed to real, dangers of the research. Davis invokes Darwinian evolutionary principles to argue that Nature abhors new pathogens. In his view, biological competition and natural selection operate in tandem to inhibit the establishment of novel pathogens in the ecosystem. Freter reviews the experimental data relevant to the question of whether E.coli $\mathrm{K} 12$ can be transformed into an epidemic pathogen. The evidence, he concludes, suggests that we cannot produce an E.coli superpathogen by recombinant DNA techniques. Nevertheless, he emphasises the importance of weakened hosts in gene-splicing experiments for the safety of laboratory personnel and recommends the use of E.coli strains incapable of growing in germ-free mice (a property of Chi 1776).

Two philosophical papers appear in Section III. Stephen Stich examines several types of moral reasoning voiced during the most active period of the debate. $\mathrm{He}$ challenges the view that scientific research should be curtailed if it can lead to the discovery of knowledge that might be disastrously misused. He believes that such a principle, if consistently applied, would paralyse all research: "It is hard to think of an area of scientific research that could not lead to the discovery of potentially dangerous knowledge." While Stich gives serious attention to the use of probability estimates of biohazards, he neglects to apply similar reasoning to the application of research programmes. The potential for misuse of science is not distributed uniformly among all research enterprises; consequently, some may warrant greater social control than others.

Carl Cohen, in his essay "On the Dangers of Inquiry and the Burden of Proof', wields a philosophical scalpel to the critics of recombinant DNA research. $\mathrm{He}$ skillfully dissects their arguments, exposing lack of rigour and their weak analogical reasoning and use of criticism, to which no response is possible ("heavy question arguments"'). Cohen's reconnaissance of the terrain of criticism is limited to the most radical critics. Moreover he says nothing about the faulty reasoning and emotional responses of proponents of laissez-faire science. There, too, one finds arguments built on conjectures and quasi-scientific findings.

This is the first collection of papers on the recombinant DNA debate by a major publisher for a non-technical audience that addresses scientific, philosophical and policy issues. The essays are generally of high quality. They centre around the controversy in the US up to 1977 . Since that time new issues have surfaced including the patenting of novel life forms, the rise of commercial interest in recombinant DNA techniques, the health of workers in large scale fermentation plants, and the disposal of by-products in production.

The weakness of this collection is in its failure to cover the political and sociological context of the debate. With the slight exception of an essay by sociologist Max Heirich on how the funding of science affects decision-making about science, there is no treatment of the key determinants that shaped DNA policy in the US. Factors of interest are: the 
effectiveness of the scientific lobby; the commercial ties of scientists in the recombinant DNA field; the control of the risk assessment process; the ability of scientists to contain the issues to laboratory biohazards; the role of environmental groups; and the politics of the Recombinant DNA Advisory Committee.
We shall await another collection of papers to bring the issues up to date and address these critical factors.

Sheldon Krimsky is Acting Director of the Program in Urban Social and Environmental Policy at Tufts Unversity, Medford, Massachusetts.

\section{Synthetic biology}

\section{Richard Roblin}

A Double Image of the Double Helix: The Recombinant DNA Debate. By Clifford Grobstein. Pp. 177. (Freeman: San Francisco and Reading, UK, 1979.) Hardback £6.90; \$11; paperback £3.50; $\$ 5.95$.

THE tone of books about the recombinant DNA policy debate has both reflected and fueled the intensity of public concern. As the debate grew heated during 1976-78, books by journalists and science-writers vividly detailed the early history of the controversy, and discussed possible biohazards. In the quieter atmosphere of 1979, Clifford Grobstein has contributed a balanced, analytical view of the American sector of the recombinant DNA landscape which emphasises the science and public policy issues thrown up by the turmoil. In doing so, he has written an excellent primer for the next stage of discussion about recombinant DNA policy issues.

Grobstein's book will be read with profit by a variety of readers. Here, interested members of the public will find an outline of the relevant science, a history of the controversy, and thought-provoking discussions of exploration, risk and research regulation. Scientists should find interesting Grobstein's interpretations of the social and political context of their research, even though they may not like the world which he describes. Bureaucrats and legislators should ponder Grobstein's comments on the incompleteness and instability of current public policy on recombinant DNA research. In Grobstein's opinion, failure to extend application of the NIH Recombinant DNA Research Guidelines to industrial as well as academic research risks undercutting their effectiveness.

One of the major sections of the book deals with the issues surrounding regulation of basic research. Grobstein finds such regulation generally distasteful, and articulates several requirements for sound regulation of research. He views continued research and expansion of human knowledge as "essential to the public interest", and would restrict these only when "there is compelling evidence of clear and present danger." However reassuringly familiar this criterion sounds to American ears, how would it apply in the recombinant DNA case? The conjectural nature of recombinant DNA biohazards remains the central intellectual dilemma of recombinant DNA policy. Except for intentionally malevolent applications, there never was, and may never be, compelling evidence of clear and present danger in the use of recombinant DNA techniques. What policy to follow given this uncertainty remains the central issue of the recombinant DNA debate. Does this mean that Grobstein believes the guidelines approach and the concommitant public and legislative furore to be an example of unsound regulation? He doesn't say, and I believe he would have made his book better if he had been more specific in this and several other places.

One thorny problem associated with the recombinant DNA debate is the role of the public in policy formation. If there are conjectured risks to public well-being because of the use of recombinant DNA techniques, then should the public have a say in how these techniques are to be used? Grobstein points out the tendency to apply criteria and procedures developed for regulation of human experimentation to recombinant DNA research. This analogy led some to suggest that appropriate policy for recombinant DNA research required something like a public 'informed consent' before proceeding with widespread use of the technique. Grobstein raises, but does not directly answer, the question of whether this extension of the principles of risk-benefit calculation and informed consent is appropriate for research in general (or recombinant DNA in particular). My own feelings are that these criteria are not appropriate where risks are conjectural, because meaningful risk-benefit estimations cannot be made. In addition, why single out the area of recombinant DNA research, when public "informed consent" has not been seriously urged in other research situations (for example, deepspace exploration) where risks could also be conjectured?

Inevitably, in an area as fast moving as recombinant DNA research, the pace of new discoveries outstrips the rate at which books can be conceived, written and published about them. Thus, Grobstein mentions only in a footnote the recently discovery that the DNA sequences which code for several eukaryotic viral and cellular proteins are not all adjacent to one another as they are in bacterial DNA. The discovery of 'split genes' and RNA splicing in higher eukaryotic cells, and the lack of evidence for RNA splicing mechanisms of comparable specificity in $E$. coli, have led many scientists to conclude that split eukaryotic viral and cellular genes will not be correctly translated into functional proteins in $E$. coli. If many eukaryotic genes are split and cannot produce functional proteins in $E$. coli, then the chance of producing pathogenic $E$. coli through 'shotgun' cloning of eukaryotic DNA segments is reduced still further. These arguments were partly responsible for the considerable reduction in containment for such cloning experiments in the December 1978 revision of the $\mathrm{NIH}$ Guidelines. It is unfortunate that Grobstein was unable to include the impact of this new information in his discussion of potential risks in recombinant DNA research.

Grobstein ends his book with a suggestion that a presidential study commission be appointed to work toward a comprehensive assessment of issues generated by the recombinant DNA debate. He feels that this would create a needed arena "in which all issues can be examined and which gives full access to all interested parties and experts"'. However, since Grobstein's book was written, there have been significant changes in both the content and administration of American recombinant DNA policy. Estimates of the possible risks of recombinant DNA experimentation have dropped further. Accordingly, containment requirements for several types of experiments have been reduced, and significant supervisory authority over recombinant DNA experiments has been delegated to local Institutional Biosafety Committees. The NIH Recombinant DNA Advisory Committee (RAC) has been enlarged to 25 members, thus expanding its expertise and diversifying it politically. Meetings of the RAC have become a national forum for debating and voting to recommend changes in the NIH Guidelines, the chief ingredient in current American recombinant DNA research policy. RAC procedures, which provide for prior publication of proposals to be discussed and publicly accessible meetings, have opened a permanent channel for public input into decision-making on recombinant DNA research policy. In addition, the major scientific and procedural objections of critics like Sinsheimer, Wald and King have either been accommodated or been found to be generally unpersuasive. In the light of these recent developments, one wonders whether Grobstein would continue to advocate a presidential study commission.

Given the current trend, we are at the beginning of a period in which the NIH Guidelines will be partially or completely 